\title{
Inadequate Laboratory Facilities and Utilization: Pedagogical Hindrance to Students' Academic Performance in Biology in Senior Secondary Certificate Examination in Zaria Metropolis, Kaduna State, Nigeria
}

\author{
Dike Ngozi $\mathrm{I}^{1} \&$ Salisu Halima ${ }^{1}$ \\ ${ }^{1}$ Department of Biology, School of Science, Federal University of Education, Zaria, Kaduna State, Nigeria \\ Correspondence: Dike Ngozi I, Department of Biology, School of Science, Federal University of Education, \\ Zaria, Kaduna State, Nigeria. E-mail: ngozidike20002000@yahoo.com
}

Received: April 7, 2015

Accepted: June 4, 2015

Online Published: August 25, 2015

doi:10.5539/ibr.v8n9p124

URL: http://dx.doi.org/10.5539/ibr.v8n9p124

\begin{abstract}
The study is designed to find out the availability and utilization of laboratory facilities and their implication in the performance of students in Biology in Senior Secondary Certificate Examination (SSCE) in Zaria metropolis of Kaduna state. Random sampling technique was used to select 5 senior secondary schools from the 12 government senior secondary schools in the study area. The sample comprised 400 students selected from 5,423 students and all 16 science teachers of the selected schools. The study adopts the survey design. The instrument for the study tagged Secondary School Laboratory Facilities Questionnaire for Teachers and Students (SSLFQT and SSLFQS) were constructed by the researchers. The instrument was considered to be standard, valid and reliable. The research questions were answered by the statistical mean while the hypotheses were analyzed using the chi square and its cross tabulation statistics. The findings of the study revealed inadequate availability and utilization of laboratory facilities in the senior secondary schools. Inadequate laboratory facilities affect meaningful teaching and learning in schools and hindrance to academic performance and hence the significant relationship between the laboratory facilities and the performance of students in Biology in the SSCE as revealed by the findings. It was recommended among others that the laboratories in the senior secondary schools should be equipped by the government in conjunction with the stakeholders and the teachers adequately trained on the effective utilization of the facilities through in-house training for enriching tomorrow.
\end{abstract}

Keywords: laboratory facilities, secondary schools, availability, utilization, students' performance

\section{Introduction}

Biological disciplines imply a significant responsibility for the protection and welfare of all living species. Any advances in medicine, dealing with environmental issues or biotechnology depend on an understanding of living organisms (Nahie, 1999). As one of the core subjects in senior secondary schools in Nigeria, Biology is of great value in determining and shaping the future of the student and hence the teaching and learning of Biology at the senior secondary school level is of paramount importance.

As a science subject, scientific inquiry is the primary process by which scientific knowledge is gained. One of the most effective vehicles by which the process of inquiry can be learnt is the laboratory where the student experiences first hand, the inquiry process (National Association of Biology Teachers, 2005). Thus, the study in a laboratory is an integral and essential part of a biology course. Biology laboratory activities are hands-on experiences which emphasis process skills (Dike, 2008) which Agbo (2003) posited as motor skills that help the scientists to find answers to problems and enhance the learning of science. Laboratory activities also encourage students to construct knowledge by interaction with laboratory materials as they solve problems. Ado (2003) further opined that it is very necessary that students manipulate materials and equipped in learning of biology through equipment; this will help them not only to acquire science process skills and new knowledge but also scientific attitude such as honesty, open-mindedness and cooperation as moralities of science and enhance understanding and retention of difficult concepts and procedures. Laboratory facilities give students some basic insight into scientific concepts and leave them with feeling of the reality of science which in turn improves their academic performance in examinations (Habu, 2005). 
Yet studies have shown that science laboratories in Nigeria senior secondary schools are poorly or inadequately equipped (Cirfat \& Zumyil, 2000; Onipede, 2003; Adeyemi, 2008; Ado 2009; Lakpini \& Atadoga, 2012) which are consistent with those of other countries. Jones (1990) surveyed teacher provision in the sciences in many other countries and also found that $45 \%$ of the schools indicated insufficient laboratories. Thousands of schools in South Africa for instance lack the infrastructure necessary to provide learners with the quality education which they are legally entitled to receive. The DBE's National Education Infrastructure Management System (NEIMS) Report published in May, 2011, which provided detailed statistics on the lack of resources at public schools across the country revealed that of the 24,793 public ordinary schools, 21,021 do not have any laboratory facilities while only 1,231 have stocked laboratories (Equal Education, 2013). These lead to poor performances by the students. Students' performance in the Secondary School Certificate Examination (SSCE) is one of the criteria for measuring and establishing the effectiveness of Nigerian secondary schools. The poor performance of senior secondary students in sciences including Biology has been persistent over the years. The West African Examination Council (WAEC) reports for May/June 1997 gave the percentage pass at credit level in physics, chemistry and biology as $10.03 \%, 25 \%$ and $16.76 \%$ respectively (Abu, 2000). WAEC Reports (2002) still showed that the performance of students in the SSCE is on the decline. Alimi et al. (2012) further observed that 2009 was another year of poor results across all states of the federation. Okpala (2010) stated that candidates who obtained credit passes in five subjects and above including English and Mathematics between 2005 and 2009 are $8.53 \%, 13-32 \%, 27.74 \%, 10.53 \%$ and $1.80 \%$ respectively. WAEC reports for May/June 2010 gave the percentage pass with five credits including English and Mathematics as 24-95\% and for November/December 2010 as $20.04 \%$, a development which has given the government and all the stakeholders a lot of concern.

Though many other factors have been attributed to the poor performance such as quality of instruction as teachers still use the traditional pedagogical approach of 'stand and deliver' method where students would sit in their seats and passively receive information, learning environment, population explosion, teacher factor, lack of incentive/staff welfare, poor attitude of students to work to mention but a few, available statistics from WAEC and NECO on senior secondary students performance in biology reveal very poor results in laboratory practical. This is due to poor acquisition of science process skills by students because their teachers were unable to conduct practical lessons as they would like to (Keister, 1992). Teachers and students are struggling to teach and learn with inadequate and antiquated facilities (Dike, 2011). This is at-variance with the tenets of education in Nigeria which stipulates that education should aim at helping the child acquire appropriate skills, abilities and competences both mental and physical as equipment for individual not only to excel in school but to live and contribute to the development of his society (Ukpai et al., 2014). This paper attempts to further investigate the inadequacy and poor utilization of laboratory facilities on the performance of senior secondary school students in the SSCE.

\subsection{Objectives of the Study}

The objectives of the study are to:

1) Assess the availability of biology laboratory facilities in the senior secondary schools in Zaria metropolis in Kaduna State, Nigeria;

2) Assess the extent of use of these facilities in the schools mentioned above;

3) Determine the trends of students' performance in Biology at the SSCE for five years;

4) Determine the relationship between the availability of laboratory facilities and students' performance in Biology at the SSCE.

\subsection{Statement of the Problem}

It is no more news that the general performance of students in the SSCE in science subjects including Biology has not been impressive in the past few decades despite efforts by the different levels of government and all stakeholders to improve performance of the students. A number of factors have been identified as contributory to this poor performance among students and inadequate/insufficient laboratory facilities in our secondary schools which cannot cater for practical lessons top the list in the science education literature. This constitutes a pedagogical hindrance in the effective teaching and learning of Biology concepts. It is against this that this study was undertaken to investigate the relationship between the availability and use of laboratory facilities and their effects on students' academic performance at senior secondary school Biology examinations focusing on Zaria metropolis, Kaduna State, Nigeria. Therefore the following research questions become imperative:

1) Are there sufficient biology laboratory facilities in the senior secondary schools in Zaria Metropolis?

2) Are the teachers in the schools qualified to make use of the available laboratory facilities? 
3) To what extent do teachers and students make use of the available laboratory facilities?

4) What is the trend in the performance of students in Biology in the SSCE in Zaria from 2006-2010?

5) Is there any significant relationship between the availability of laboratory facilities and the performance of students in Biology in the SSCE in Zaria Metropolis in individual years, 2006-2010?

6) Is there any significant relationship between the availability of laboratory facilities and the performance of students in Biology in the SSCE in Zaria metropolis in combined years, 2006-2010?

\subsection{Hypotheses}

1) There is no significant relationship between the availability of laboratory facilities and the performance of students in Biology in the SSCE in Zaria metropolis in individual years, 2006-2010.

2) There is no significant relationship between the availability of laboratory facilities and the performance of students in Biology in the SSCE in Zaria metropolis in combined years, 2006-2010.

\section{Methodology}

This study utilized the descriptive survey design which involves studying the subject by collecting and analyzing data from a group selected/sample from among the subject. This allows one to generalize the findings from the selected group/sample to the population. A constructed questionnaire and the schools biology laboratory inventory books were used to obtain the data on the availability of laboratory facilities. The students' SSCE results for five years (2006-2010) were obtained from the schools' examinations offices.

\subsection{Population and Sampling Technique}

The population of this study includes the twelve government senior secondary schools in Zaria Local Government Area (LGA). A sample of five Senior Secondary Schools was selected by simple random sampling technique from the total population. The selected schools were Barewa College, Zaria, Alhuda-huda College, Zaria, Government Girls Secondary School, Kongo, Government Senior Secondary School, Zaria and Government Girls Secondary School, Kofar Gayan. The names of the schools were abbreviated as BCZ, ACZ, GGSSK, GSSSZ and GGSSKG respectively. Those in the senior secondary schools comprised 5,423 and out of this number, 400 students were selected, 80 students in each of the senior secondary schools comprising 40 senior secondary 11 (SS11) and 40 senior secondary III (SS III). All the 16 biology teachers in the five selected schools were selected for the study.

\subsubsection{Instruments for Data Collection and Scoring}

The questionnaire instrument employed in this study was constructed by the researchers. It had two sections, A and B; section A tagged Secondary School Laboratory Facilities Teachers Questionnaire (SSLFTQ) was for biology teachers while section B-Secondary School Laboratory Facilities Students Questionnaire (SSLFSQ) was for the students in the sampled schools. The schools' biology laboratory books were used for essential information about laboratory facilities. Another instrument used for the study to collect data was the grades of the students in the sample groups in the SSCE from 2006-2010. The instruments were considered to be standard, valid and reliable.

The questionnaires were administered to the biology teachers and students by the researchers personally to ensure fairness, objectivity and for explanation of unclear issues in the questionnaire and the responses were then collected. The data obtained through the questionnaire and the schools' biology laboratory inventory books which gave information about the availability and use of the laboratory facilities were ranked into an adopted four point Linkert scale of measurement (Ado, 2004). The students' SSCE results from 2006-2010 from the five schools were also ranked accordingly by using the grades the students obtained and assigning them with different points ranging from 0-4.

\subsubsection{Statistical Method of Data Analysis}

The data collected through structured questionnaire from the selected schools were analyzed using simple percentage. The data on the available facilities were correlated with the scores of SSCE results for the individual years and then for the combined years (2006-2010) using the chi square and its cross tabulator statistics. Each item is presented on a table for clarity of purpose.

\section{Results}

Question 1: Are there sufficient biology laboratory facilities in the senior secondary schools in Zaria metropolis? 
Table 1. Distribution of facilities in schools biology laboratories

\begin{tabular}{lccc}
\hline Schools & No of facilities prescribed by WAEC & No of available facilities in schools & Percentage availability \\
\hline BAZ & 135 & 89 & 65.9 \\
ACZ & 135 & 65 & 48.1 \\
GGSSK & 135 & 76 & 56.3 \\
GGSSZ & 135 & 0 & 0 \\
GGSSKG & 135 & 26 & 19.3 \\
Mean & 135 & 51.2 & 37.9 \\
\hline
\end{tabular}

Table 1 reveals that the school with the highest facilities was BCZ with 89 (65.9\%) followed by GGSSK with 76 (56.3\%), ACZ with 65(48.1\%), GGSSKG with 26(19.3\%). The least was GSSSZ which had no facilities (0\%).

Table 2. Are you satisfied with the number of laboratory facilities at your disposal?

\begin{tabular}{ccc}
\hline Satisfied & Frequency & Percentage $(\boldsymbol{\%})$ \\
\hline Yes & 5 & 31.2 \\
No & 11 & 68.8 \\
Total & $\mathbf{1 6}$ & $\mathbf{1 0 0}$ \\
\hline
\end{tabular}

Table 2 shows that $68.8 \%$ of the teachers were dissatisfied with the availability of laboratory facilities in their schools while $31.2 \%$ were satisfied revealing that the laboratory facilities in the schools were inadequate.

Table 3. Do you improvise for laboratory facilities in your school?

\begin{tabular}{ccc}
\hline Improvise & Frequency & Percentage (\%) \\
\hline Yes & 14 & 87.5 \\
No & 2 & 12.5 \\
Total & $\mathbf{1 6}$ & $\mathbf{1 0 0}$ \\
\hline
\end{tabular}

Table 3 shows that $87.5 \%$ of the teachers improvise for laboratory facilities while $12.5 \%$ do not.

Question 2: Are the teachers in the schools qualified to teach or use the laboratory facilities?

Table 4. Qualifications of teachers in the various schools

\begin{tabular}{ccc}
\hline Qualifications & Frequency & Percentage (\%) \\
\hline Diploma & 0 & 0 \\
NCE & 5 & 31.2 \\
HND & 0 & 0 \\
BA/BSc & 0 & 0 \\
BEd/BSc.Ed & 9 & 56.3 \\
PGDE & 2 & 12.5 \\
MEd/MSc & 0 & 0 \\
PhD & 0 & 0 \\
Total & $\mathbf{1 6}$ & $\mathbf{1 0 0}$ \\
\hline
\end{tabular}

Table 4 shows that $9(56.3 \%)$ of the teachers had BEd/BSc.Ed, $5(31.2 \%)$ had NCE, 2(12.5\%) had BA/BSc + PGDE and none had diploma, HND, BA/BSc., MEd/MSc and PhD indicating that all the teachers in the schools were qualified to teach with laboratory facilities.

Question 3: To what extent do teachers and students make use of available laboratory facilities? 
Table 5. Do teachers hold practical lessons in the laboratory?

\begin{tabular}{lccc}
\hline Schools & Yes & No & Total \\
\hline BCZ & 40 & 40 & 80 \\
ACZ & 32 & 48 & 80 \\
GGSSK & 20 & 60 & 80 \\
GSSSZ & 31 & 49 & 80 \\
GGSSKG & 18 & 62 & 80 \\
Mean & 28.20 & 51.80 & 80 \\
\hline
\end{tabular}

Table 5 shows that $28.20 \%$ of the respondents/students indicated that the teachers hold practical lessons in the laboratories while $51.80 \%$ indicated that they do not do so.

Table 6. To what extent do teachers make use of available laboratory facilities?

\begin{tabular}{lcc}
\hline Degree of participation & Frequency & Percentage \% \\
\hline Always & 3 & 18.75 \\
Most of the time & 3 & 18.75 \\
Occasionally & 10 & 62.50 \\
Rarely & 0 & 0 \\
Never & 0 & 0 \\
Total & $\mathbf{1 6}$ & $\mathbf{1 0 0}$ \\
\hline
\end{tabular}

Table 6 reveals that $10(62.5 \%)$ of the respondents/teachers occasionally utilize the available laboratory facilities; $3(18.75 \%)$ utilize them always and most of the time respectively while none of them never or rarely utilize them.

Table 7. How often do teachers utilize laboratory facilities during practical lessons?

\begin{tabular}{lcccccc}
\hline Schools & Always & Most of time & Occasionally & Rarely & Never & Total \\
\hline BCZ & 31 & 18 & 26 & 03 & 02 & 80 \\
ACZ & 10 & 09 & 14 & 30 & 17 & 80 \\
GGSSK & 08 & 11 & 20 & 16 & 25 & 80 \\
GSSSZ & 02 & 07 & 20 & 17 & 34 & 80 \\
GGSSKG & 05 & 09 & 31 & 25 & 10 & 80 \\
Total & 56 & 54 & 111 & 91 & 88 & 400 \\
Percentage (\%) & 14.0 & 13.50 & 27.75 & 22.75 & 22.0 & 100 \\
\hline
\end{tabular}

Table 7 reveals that $111(27.75 \%)$ of the students indicated that teachers occasionally utilize the laboratory facilities during practical lessons; $91(22.78 \%)$ were of the view that teachers rarely utilize them; $88(22.0 \%)$ indicated that teachers never utilize them while 56(14.0\%) and 54(13.5\%) indicated that teachers utilize them always and most of the time respectively.

Table 8. How often do students utilize laboratory facilities during practical lesions?

\begin{tabular}{lcccccc}
\hline Schools & Always & Most of time & Occasionally & Rarely & Never & Total \\
\hline BCZ & 06 & 36 & 18 & 13 & 07 & 80 \\
ACZ & 10 & 14 & 14 & 26 & 16 & 80 \\
GGSSK & 09 & 10 & 23 & 22 & 16 & 80 \\
GSSSZ & 02 & 06 & 15 & 21 & 36 & 80 \\
GGSSKG & 0 & 11 & 24 & 38 & 07 & 80 \\
Total & 27 & 77 & 94 & 120 & 82 & 400 \\
Percentage (\%) & 6.75 & 19.25 & 23.50 & 30.0 & 20.50 & 100 \\
\hline
\end{tabular}

Table 8 depicts that $120(30 \%)$ of the students rarely utilize the laboratory facilities during practical lessons; $94(23.50 \%)$ indicated that they utilize them occasionally; $82(20.50 \%)$ indicated that they have never utilized 
them; $77(19.25 \%)$ indicated that they use them most of the time while $27(6.75 \%)$ were of the view that they use them always.

Question 4: What is the trend in the performance of students in biology in the SSCE in Zaria and its relationship with the availability of materials in the schools from 2006-2010?

Table 9. Results of students performance $\left(\mathrm{A}_{1}-\mathrm{E}_{8}=\right.$ Pass and $\mathrm{F}_{9}=$ Fail $)$ in Biology in the SSCE in Zaria from 2006-2010

\begin{tabular}{lccccc}
\hline Schools & \multicolumn{5}{c}{ SSCE Biology Results } \\
\cline { 2 - 5 } & $\mathbf{2 0 0 6}$ & $\mathbf{2 0 0 7}$ & $\mathbf{2 0 0 8}$ & $\mathbf{2 0 0 9}$ & $\mathbf{2 0 1 0}$ \\
\hline BCZ & $202 / 426$ & $364 / 398$ & $417 / 441$ & $269 / 402$ & $238 / 399$ \\
ACZ & $125 / 810$ & $247 / 409$ & $251 / 455$ & $101 / 483$ & $180 / 445$ \\
GGSSK & $145 / 479$ & $26 / 447$ & $268 / 279$ & $66 / 293$ & $334 / 468$ \\
GSSSZ & $165 / 727$ & $308 / 589$ & $181 / 229$ & $49 / 271$ & $319 / 649$ \\
GGSSKG & $86 / 336$ & $116 / 312$ & $144 / 480$ & $136 / 312$ & $184 / 372$ \\
Total no of students & 2778 & 2155 & 1884 & 1761 & 2333 \\
No passed & 723 & 1296 & 261 & 621 & 1255 \\
\% No passed & $26.03 \%$ & $60.14 \%$ & $66.93 \%$ & $35.26 \%$ & $53.79 \%$ \\
No failed & 2055 & 859 & 623 & 1140 & 1078 \\
\% no failed & $73.97 \%$ & $39.86 \%$ & $33.07 \%$ & $64.74 \%$ & $46.21 \%$ \\
\hline
\end{tabular}

Table 9 indicates that the number of students that failed were highest in 2006 with $73.97 \%$ as against $26.03 \%$ that passed. The results improved steadily in the following two years 2007 and 2008 with $39.86 \%$ and $33.07 \%$ failures and $60.14 \%$ and $66.93 \%$ passes respectively. In 2009 , the trend changed with $64.74 \%$ failures and $35.26 \%$ passes. It improved slightly in 2010 with those that failed at $46.21 \%$ and those that passed at $55.79 \%$

Table 10. Comparison of available laboratory facilities in the schools, utilization and performance of students in Biology in the SSCE from 2006-2010

\begin{tabular}{|c|c|c|c|c|}
\hline Schools & $\%$ available facilities & $\%$ utilization & $\%$ performance $\left(A_{1}-E_{8}=\right.$ pass $)$ & $\%$ performance $\left(\mathbf{F}_{9}=\right.$ fail $)$ \\
\hline $\mathrm{BCZ}$ & 65.90 & 97.50 & 68.70 & 31.30 \\
\hline $\mathrm{ACZ}$ & 48.10 & 78.75 & 37.70 & 62.30 \\
\hline GGSSK & 56.30 & 68.75 & 49.70 & 50.30 \\
\hline GSSSZ & 0.00 & 57.50 & 36.90 & 63.10 \\
\hline GGSSKG & 19.30 & 87.50 & 37.60 & 62.40 \\
\hline
\end{tabular}

The result in Table 10 shows that BCZ with the highest available facilities of $65.90 \%$ and utilization (97.50\%) also has the highest performance of $68.70 \%$ and the least failure of $31.30 \%$ followed by GGSSK with $56.3 \%$ of available facilities, $68.75 \%$ utilization, $49.70 \%$ successful candidates and $50.30 \%$ failures. ACZ is next with $48.1 \%$ of available facilities, $78.75 \%$ utilization, $37.70 \%$ of passes and $62.30 \%$ of failures followed by GGSSKG which had $19.30 \%$ of available laboratory facilities, $87.50 \%$ utilization with $37.60 \%$ passes and $62.40 \%$ failures. GSSSZ has little or no available laboratory facilities, least utilization (57.50\%) and had the least number of successful students (36.9\%) and the highest failures (63.1\%).

Table 11. Availability/performance cross tabulation for the combined years 2006-2010

\begin{tabular}{lccc}
\hline Availability & \multicolumn{2}{c}{ Performance } & Total \\
\cline { 2 - 4 } & Pass & 5189 & 6355 \\
\hline Count & 1166 & $81.6 \%$ & $100.0 \%$ \\
Not available \% within & $18.4 \%$ & $90.5 \%$ & $58.3 \%$ \\
\% within performance & $22.6 \%$ & 546 & 4556 \\
Count & 4010 & $12.0 \%$ & $100.0 \%$ \\
Available \% within availability & $88.0 \%$ & $9.5 \%$ & $41.7 \%$ \\
\% within performance & $77.4 \%$ & 5735 & 10911 \\
Count & 5178 & $52.6 \%$ & $100.0 \%$ \\
Total \% within availability & $47.4 \%$ & $100.0 \%$ & $100.0 \%$ \\
\hline within performance & $100.0 \%$ & & \\
\end{tabular}


The result in Table 11 reveals $88.0 \%$ passes and $12.0 \%$ failures in schools with available laboratory facilities; $81.6 \%$ failures and only $18.4 \%$ passes in schools without the available facilities in the combined years 2006-2010.

Question 5: Is there any significant relationship between the availability of laboratory facilities and the performance of students in Biology in the SSCE in Zaria metropolis in the individual years, 2006-2010?

\section{Hypothesis 1}

There is no significant relationship between the availability of laboratory facilities and the performance of students in biology in the SSCE in Zaria metropolis in the individual years, 2006-2010.

Table 12a. Chi-square test of the relationship between the availability of laboratory facilities and the performance of students in biology in the SSCE in Zaria in 2006

\begin{tabular}{lccc}
\hline & Value & Df & P \\
\hline Pearson chi-square & $2492.790^{\mathrm{a}}$ & 1 & 0.000 \\
Pearson chi-square critical $^{\mathrm{a}}$ Continuity correction $^{\mathrm{b}}$ & 3.481 & & 0.000 \\
Likelihood ratio & 2488.316 & 1 & 0.000 \\
Fisher's exact test & 2829.873 & & 0.000 \\
Linear-by-linear association & & 1 & \\
No of valid cases & 2491.892 & & \\
\hline
\end{tabular}

Note. a. O cells $(0.0 \%)$ have expected count less than 5.

b. Computed only for $2 \times 2$ table.

The result in Table 12a shows calculated chi-square value (2492.790) and chi-square critical value (3.841) at $\mathrm{P}=$ 0.00 . Since the calculated chi-square (2492.790) is greater than the chi-square critical (3.841) at $\mathrm{P} \leq 0.05$ level of significance, the null hypothesis of no significant relationship between laboratory facilities and performance of students in Biology in the SSCE in Zaria in 2006 is rejected.

Table 12b. Chi-square test of the relationship between the availability of laboratory facilities and the performance of students in biology in the SSCE in Zaria in 2007

\begin{tabular}{llll}
\hline & Value & Df & P \\
\hline Pearson chi-square & $1661.396^{\mathrm{a}}$ & 1 & 0.000 \\
Pearson chi-square critical & 3.841 & & \\
Continuity correction $^{\mathrm{b}}$ & 1657.276 & 1 & 0.000 \\
Likelihood ratio $^{\text {Fisher's exact test }}$ & 1799.245 & 1 & 0.000 \\
Linear-by-linear association & & & \\
No of valid cases & 1660.625 & 1 & 0.000 \\
\hline
\end{tabular}

Note. $\mathrm{s}(0.0 \%)$ have expected count less than 5 .

b. puted only for $2 \times 2$ table.

The result in Table 12b indicates that the calculated chi-square value (1661.396) is greater than the critical value (3.841) at $\mathrm{P} \leq 0.05$ level of significance. Therefore the null hypothesis is rejected, that is, there is a significant relationship between the availability of laboratory facilities and the performance of students in biology in the SSCE in Zaria in 2007.

Table 12c. Chi-square test of the relationship between the availability of laboratory facilities and the performance of students in biology in the SSCE in Zaria in 2008

\begin{tabular}{llll}
\hline & Value & Df & P \\
\hline Pearson chi-square & $1812.555^{\mathrm{a}}$ & 1 & 0.000 \\
Pearson chi-square critical & 3.841 & & 0.000 \\
Continuity correction $^{\mathrm{b}}$ & 1808.130 & 1 & \\
\hline
\end{tabular}




\begin{tabular}{lcc}
\hline Likelihood ratio & 2212.561 & 1 \\
Fisher's exact test & & 0.000 \\
Linear-by-linear association & 1811.593 & 1 \\
No of valid cases & 1884 & 0.400 \\
\hline
\end{tabular}

Note. a. O cells $(0.0 \%)$ have expected count less than 5 .

b. Computed only for $2 \times 2$ table.

The result in table $12 \mathrm{c}$ shows that the calculated chi-square of 1812.555 is greater than the critical chi-square of 3.841 at $\mathrm{P} \leq 0.05$ level of significance; the null hypothesis of no significant relationship between the availability of laboratory facilities and the performance of students in biology in the SSCE in Zaria in 2008 is rejected.

Table 12d. Chi-square test of the relationship between the availability of laboratory facilities and the performance of students in biology in the SSCE in Zaria in 2009

\begin{tabular}{|c|c|c|c|}
\hline & Value & Df & $\mathbf{P}$ \\
\hline Pearson chi-square & $443.403^{\mathrm{a}}$ & 1 & 0.000 \\
\hline Pearson chi-square critical & 3.841 & & \\
\hline Continuity correction ${ }^{b}$ & 441.204 & 1 & 0.000 \\
\hline Likelihood ratio & 445.068 & 1 & 0.000 \\
\hline \multicolumn{4}{|l|}{ Fisher's exact test } \\
\hline Linear-by-linear association & 443.151 & 1 & 0.000 \\
\hline No of valid cases & 1761 & & \\
\hline
\end{tabular}

Note. a. O cells $(0.0 \%)$ have expected count less than 5 .

b. Computed only for a $2 \times 2$ table.

The result in $12 \mathrm{~d}$ reveals the calculated chi-square of 443.403 and the critical chi-square of 3.841 at $\mathrm{P}=0.00$ level of significance. Since the calculated chi-square (443.403) is greater than the critical chi-square (3.841) at $\mathrm{P}$ $\leq 0.05$ level of significance, the null hypothesis is rejected, that is, there is a significant relationship between the availability of laboratory facilities and the performance of students in biology in the SSCE in Zaria in 2009.

Table 12e. Chi-square test of the relationship between the availability of laboratory facilities and the performance of students in biology in the SSCE in Zaria in 2010

\begin{tabular}{llll}
\hline & Value & Df & P \\
\hline Pearson chi-square & $1841.304^{\mathrm{a}}$ & 1 & 0.001 \\
Pearson chi-square critical $_{\text {Continuity correction }}{ }^{\mathrm{b}}$ & 3.841 & & \\
Likelihood ratio $^{\text {Fisher's exact test }}$ & 1837.733 & 1 & 0.000 \\
Linear-by-linear association $_{\text {No of valid cases }}^{2220.905}$ & 1 & 0.000 \\
\hline
\end{tabular}

Note. a. cells $(0.0 \%)$ have expected count less than 5 .

b. Computed only for $2 \times 2$ table.

The result in table 12e shows that the calculated chi square of 1841.304 is greater than the critical chi-square of 3.841 at $\mathrm{P} \leq 0.0$ level of significance; the null hypothesis of no significant relationship between the availability of laboratory facilities and the performance of students in Biology in the SSCE in Zaria in 2010 is rejected.

\section{Question 6}

Is there any significant relationship between the availability of laboratory facilities and the performance of students in Biology in the SSCE in Zaria in the combined years 2006-2010?

\section{Hypothesis 2}

There is no significant relationship between the availability of laboratory facilities and the performance of students in Biology in the SSCE in Zaria in the combined years 2006-2010. 
Table 13. Chi-square test of the relationship between the availability of laboratory facilities and the performance of students in biology in the SSCE in Zaria in the combined years 2006-2010

\begin{tabular}{llll}
\hline & Value & Df & P \\
\hline Pearson chi-square & $5162.161^{\mathrm{a}}$ & 1 & 0.000 \\
$\begin{array}{l}\text { Pearson chi-square critical } \\
\text { Continuity correction }{ }^{\mathrm{b}}\end{array}$ & 3.841 & & \\
Likelihood ratio $_{\text {Fisher's exact test }}$ & 5159.368 & 1 & 0.000 \\
Linear-by-linear association & 5694.943 & 1 & 0.000 \\
No of valid cases & & & \\
\hline
\end{tabular}

Note. a. O cells $(0.0 \%)$ have expected count less than 5.

b. Computed only for a 2 × 2 table.

The result in Table 13 indicates that the calculated chi-square (5162.161) is greater than the critical chi-square (3.841) at $\mathrm{P} \leq 0.05$ level of significance. Therefore the null hypothesis is rejected, that is, there is a significant relationship between the availability of laboratory facilities and the performance of students in Biology in the SSCE in Zaria in the combined years, 2006-2010.

\section{Discussion of Results}

Table 1 reveals that there are inadequate and in some cases unavailable laboratory facilities (37.9\%) in the senior secondary schools in Zaria metropolis. This agrees with the findings of Ndu (1980), Okafor (2000), Ado (2009) and Lakpini and Atadoga (2012) who reported inadequate laboratory facilities in various secondary schools in Nigeria. It is not surprising then that the teachers $(68.8 \%)$ were not satisfied with the availability of laboratory facilities in their schools as revealed in Table 2. From Table 3, the teachers $(87.5 \%)$ were found to resort to improvisation of the facilities as a way out which is in line with the findings of Olagunju (2000) and Maikano (2014) who reported the participation of teachers in the improvisation of laboratory facilities in the secondary schools.

Interestingly, Table 4 indicated that all the teachers (100\%) were qualified but $51.80 \%$ of the students in Table 5 indicated that the teachers do not hold practical lessons; a view supported by Moemeka and Omoifo (2002). Even the utilization of the available facilities by those that hold practical was done occasionally in the views of the teachers and the students (62.50\% and $27.75 \%$ respectively) as revealed in Tables 6 and 7 . Table 7 also reveals that most of the students $(44.75 \%)$ indicated that the teachers rarely or never utilize the available facilities for practical exercise. Furthermore, the result in Table 8 indicates that while some of the students themselves also utilize the facilities occasionally (23.5\%) during practical lessons, 55.5\% rarely or never utilize them. This finding is in consonance with Okafor (2000) and Cirfat and Zumyil (2007) who asserted that most of the schools where laboratory facilities are available do not utilize them effectively. This implies that the students may graduate without handling or using simple laboratory equipment such as thermometer, microscope, Bunsen burner, skeletons, food tests reagents, test tubes, flasks, measuring cylinder, preserved/life specimens to mention but a few that were listed in the questionnaire.

The result in Table 9 reveals the poor performance of students in the SSCE particularly in 2006 and 2009 which has been persistent till date. Table 10 indicates that a relationship exists between availability and utilization of facilities in the senior secondary schools and students' performance in the SSCE. The higher the availability of laboratory facilities, the higher the utilization rate and the higher the performance of students and of course the lower the failure rate. For instance, BCZ with the highest facilities (65.90\%) tended to utilize them most (97.50\%) and had the highest performance $(68.70 \%)$ and the least failure $(31.30 \%)$. Conversely, GSSSZ which had a deplorable laboratory with little or no facilities utilized them the least $(57.50 \%)$ and also had the least performance $(36.90 \%)$ and the highest failure $(63.10 \%)$. The result in Table 11 confirms higher number of passes $(88.0 \%)$ in schools with available facilities and higher failures $(81.60 \%)$ in schools without the available facilities.

Furthermore the results in Tables 12a-e and 13 indicate that there is a significant relationship between available laboratory facilities and performance of students in the SSCE. The finding is in line with Okafor (2000), Adeyemi (2008), Cynthia and Megan (2008) and Ado (2009) who in their various reports asserted significant relationship between available laboratory facilities and performance of students in the SSCE. This implies that the availability of laboratory facilities will positively enhance meaningful teaching and learning that will translate into better performance of students in the secondary schools. This of course should not be in isolation 
with other factors such as the effective utilization of the facilities, teaching methodology, teacher-student ratio, learning environment to mention but a few which will compliment it to bring the desired goal.

\section{Conclusion}

The findings of the study revealed that there are inadequate facilities in the Biology laboratories in the senior secondary schools in Zaria metropolis. From the findings, the teachers do not conduct practical lessons with the students and those that are involved, do not utilize the facilities effectively which impart negatively on students as they are not exposed to or allowed to handle the equipment. Based on the findings also, there is a significant relationship between the availability of laboratory facilities and the performance of students in the SSCE.

It can then be concluded that inadequate laboratory facilities and utilization hinder meaningful teaching and learning in the secondary schools and contribute to the persistent poor performance of students in the SSCE in Zaria, Kaduna State, Nigeria and possibly nationwide.

\section{Recommendations}

Based on the research findings, the following recommendations are made:

1). There is need to have a well-equipped biology laboratories which can be provided not only by the government but also by the Parents teachers Association (PTA), voluntary and non-voluntary organizations and philanthropists.

2). The biology teachers should be adequately trained on the effective use of all equipment in the laboratories through in-house training workshops and seminars.

3). In the absence of the standard laboratory facilities, improvisation should be encouraged and used which may provide the opportunity for creativity and innovations in both the teachers and students.

\section{References}

Abu, A. O. (2000). The effectiveness of individualized and lecture instructional methods of teaching Biology at senior secondary level of education. Zaria Journal of Educational Studies (ZAJES), 4(1\&2), 151-161.

Adeyemi, T. O. (2008). Science laboratories and the quality of output from secondary schools in Ondo State, $\begin{array}{lll}\text { Nigeria. Asian Journal of Information } & \text { 23-30. }\end{array}$ http://scialert.net/fulltext/?doi=ajim,2008.23.30

Ado, S. (2009). A survey of the relationship between availability of laboratory facilities and students academic performance among senior secondary school biology students of Malumfashi Educational Zone, Katsina State. Nigeria. Journal of Science \& Educational Research (NIJOSER), 5(1), 134-142.

Alimi, O. S., Ethinola, G. B., \& Alabi, F. O. (2012). School types, facilities and academic performance of students in senior secondary schools in Ondo State, Nigeria. International Education Studies, 5(3). http://dx.doi.org/10.5539/ies.v5n3p44

Agbo, F. O. (2003). An investigation into students' performance of practical biology skills in SSCE examinations: Implications for the biology teacher. The Jos Journal of Education, 6(2), 27-35.

Cirfat, A. B., \& Zumyil, C. F. (2000). Resource utilization in biology teaching at the secondary school: A case study of central senatorial zone of Plateau State. Proceedings of the $41^{\text {st }}$ Annual Conference of STAN, pp. 134-137.

Cynthia, U., \& Megan, T. (2008). The Walls Speak: The interplay of quality facilities, school climate, and student achievement. Journal of Educational Administration, 1(4), 55-73.

Dike, N. I. (2009). Collaborative involvement in funding biology laboratory equipment and facilities in tertiary institutions in Nigeria: Issues and approaches. Nigerian Journal of Science and Educational Research (NIJOSER), 5(1), 86-93.

Dike, V. E. (2011). Integration of instructional technologies in education: Where is Nigeria? Rerieved from $\mathrm{http} / /$ nigeriavillagesquare.com/victor-dike/integration-of-instructional-technologies-in-education-where-isnigeria.html

Equal Education. (2013). School infrastructure. Retrieved from http://www.equaleducation.org.za/page/school-infrastructure

Kalu, U. U. (2004). Students' participation in biology practical and its effect on performance in Senior Secondary School Certificate Examination in Zaria, Nigeria. Zaria Journal of Educational Studies (ZAJES), $6(1 \& 2), 152-155$. 
Habu, I. C. (2005). The influence of biological apparatus in the teaching of biology in some selected schools in Jigawa State (Unpublished B.Ed project). Department of Education, Ahmadu Bello University, Zaria, Nigeria.

Jones, E. (1990). Teacher provision in the sciences. Education Science, 140, 27-37.

Keister, J. N. (1992). The complexities of practical work in physics teaching: A case study of three secondary schools in Sierra Leone (Unpublished Thesis). Queen's University at Kingston, Canada.

Lakpini, M. A., \& Atadoga, M. M. (2012). Learning environment on senior secondary school students' academic performance in science in public secondary schools in Kaduna State. Proceedings of the $1^{\text {st }}$ African Forum of Teaching Regulatory Authority (AFTRA), 1, 190-196.

Maikano, A. (2014). Attitude of biology teachers towards improvisation of teaching aids in some selected secondary schools in Zaria LGA of Kaduna State. Paper presented at the School of Science 2014 Conference held at Federal College of Education, Zaria from $13^{\text {th }}-17^{\text {th }}$ October.

Moemeka, C. D., \& Qmoifo, C. N. (2003). The effectiveness of individualized collaborative field work and expository learning in biology students' ability to solve problems. The Jos Journal of Education, 6(2), 84-92.

Nabie, N. (1999). Importance of biology. Rerieved from http://biocab.org/Biology.html

National Association of Biology Teachers (NABT). (2005). Role of laboratory and field instruction. Rerieved from http://www.nabt.org/websites/instituions/field/docs/role\%20of\%20lab\%209\%20fie

Ndu O. F. (1980). Planning and organization of practical work in biology in secondary schools. Journal of Science Teachers Association of Nigeria (JSTAN), 18(4), 49-60.

Okafor, N. P. (2000). Laboratory resources and utilization as correlates of chemistry students' learning outcomes. Proceedings of the $41^{\text {st }}$ Annual Conference of STAN, 169-173.

Okpala, P. (2010). Season of mass failure. The Nation, April 15, 2010.

Olagunju, A. M. (2000). An investigation into teachers' attitude towards and extent of improvisation of resources for effective teaching of biology. Proceedings of the $41^{s t}$ Annual Conference of STAN, pp. 120-126.

Onipede, H. (2003). National development hinges on quality education. The Comet, January 2, 21.

Ukpai, K. U., Dike, N. I., Gambo, B. N., \& Osuoha, V. U. N. (2014). Labaratory and discussion methods of teaching biology and their effects on performance of secondary school students in Nigeria. Alvana Journal of Science, 8(special edition), 36-44.

\section{Copyrights}

Copyright for this article is retained by the author(s), with first publication rights granted to the journal.

This is an open-access article distributed under the terms and conditions of the Creative Commons Attribution license (http://creativecommons.org/licenses/by/3.0/). 